\title{
Access to Credit and the Effect of Credit Constraints on the Performance of Manufacturing Firms in the East African Region: Micro Analysis
}

\author{
Faisal Buyinza $^{1} \&$ Edward Bbaale $^{1}$ \\ ${ }^{1}$ School of Economics, Makerere University, Uganda \\ Correspondence: Faisal Buyinza, School of Economics, Makerere University, Uganda. E-mail: \\ bbkfaisal@gmail.com
}

Received: August 15, 2013

Accepted: September 5, 2013 Online Published: September 26, 2013

doi:10.5539/ijef.v5n10p85

URL: http://dx.doi.org/10.5539/ijef.v5n10p85

\begin{abstract}
The study set out to investigate the factors influencing manufacturing firms' access to credit and the effect of credit constraints on firm performance in the East African Community (EAC) using the World Bank (2006) enterprise survey for 5 EAC countries. We employed simple probit, simple OLS, tobit, and a two-step probit models. Descriptively, the top five business constraints in order of severity include; electricity outages and costs, access to finance, high and volatile tax rates, corruption, and macroeconomic instability. The majority of firms within the EAC are credit constrained with only $37 \%$ of firms in the best performing sector (metal fabrications) having obtained a loan. Quantitatively, high performing firms, exporters, medium and large firms increase the probability of credit access. Findings indicate that having access to credit and a long loan duration increase firm performance, while increase in the annual interest rate reduces firm productivity. Governments in the region should tackle the business constraints rated as very severe. EAC governments should make credit access easier by lowering the annual interest rates and also negotiating for a longer pay back period for individuals in the business sector. Governments in the region should put specific attention on those sectors which are observed to have an extreme disadvantage in accessing finance.
\end{abstract}

Keywords: credit access and constraints, sales, value added, performance

\section{Introduction and Study Concern}

The importance of bank credit in enhancing the process of economic development and growth through availing finances to manufacturing firms cannot be underscored. Credit access enhances the possibility of firms to increase their capital stock by acquiring capital goods that may not be possibly produced in the less developed country. Noteworthy is the fact that some capital goods especially plants and machinery may well be beyond the savings of the business entrepreneurs in the EAC and hence need an extra source of funding. Owing to the usually strong synergies between capital goods accumulation on the one hand and an increase in productivity and growth of firms on the other (Bbaale, 2011), countries the world over have designed purposeful policies that are aimed at enhancing the acquisition of capital goods especially in developing countries where there is an extreme disadvantage in the production of capital goods. Capital goods accumulation is a key for technological advancement of a country. Therefore, credit constraint affects a firm's technology choice by limiting the number of investment alternatives that can be considered in regard to the available resources.

Many manufacturing firms may use an inappropriate technology because it is the only one that is within the resource envelop of the firm. In some cases, even where credit is available mainly through banks, the entrepreneur may lack freedom to choose an array of machinery and software that may be more relevant to the type of technology that a firm may want to adopt. Instead, the bank's lending conditions may force firms to purchase heavy, immovable equipment that can serve as collateral for the bank. It is against this background that credit programs have been a favored intervention by donors and governments in Africa (Bigsten et al., 2000). These authors argue that the core of these interventions is the concern that credit markets are not functioning well and their malfunctioning results in low economic activity and growth. At the microeconomic level, credit constraints limit the size of firms, as well as their growth, profits, activations and liquidations; their scope of operations may 
also be limited (Monge-Naranjo et al., 2003). Thus, understanding the implications of credit constraints especially in a developing country context has always been a matter of great policy concern.

There are various pathways through which credit constraints are teething in developing countries, the EAC not an exception. One of such pathways includes the undeveloped capital market which forces entrepreneurs to rely on self-financing or borrowing informally from friends and/or relatives (Buyinza \& Bbaale, 2011). This, by extension, leads to lack of access to long-term credit for small enterprises forcing them to rely on high cost short term finance. Other pathways worth noting for the case of the EAC include the high cost of credit, high bank charges and fees. As an example, Uganda witnessed a scenario during the climaxing period of the year 2008 which testifies the need for credit among the common and low earning entrepreneurs. During the time, numerous money lenders in the name of microfinance institutions and informal money lenders came up, promising hope among the 'little investors,' by availing financial freedom through soft borrowing. The rationale behind turning to these schemes among a good number of entrepreneurs is mainly to seek alternatives and soft credit with low interest rates while making profits. Financial constraint remains a major challenge facing manufacturing firms in Uganda and the East African region at large (Buyinza \& Bbaale, 2011).

The study aimed to investigate the factors influencing access to credit by manufacturing firms within the EAC and the relationship between credit access and firm level performance measured in terms of sales and value added. This was intended to draw insights into the factors hampering access to credit by manufacturing firms in order to suggest possible policy options. In line with the study objectives, we sought to answer two pertinent research questions. First, what factors determine whether a firm has access to formal financial markets? Second, what is the relationship between credit access and firm productivity? In line with this question we hypothesize that firms having access to credit outperform their counterparts. Large and exporting firms have a higher probability of credit access and, by extension, outperform their counterparts. While the existence of credit market imperfections is uncontestable in the context of the EAC, and that credit constrained firms are also poor performers, an empirical regularity has been missing for the case of the East African Community (EAC).

The findings from the study will be of great importance to the government policy makers in an effort to eliminate credit constraints especially amongst small entrepreneurs. The findings will also offer insights into the types of manufacturing firms/sectors that are more credit constrained than others so as to help government and other stakeholders know where to target their efforts in an attempt to providing access to easy and cheap credit. The findings will point out the impact of annual interest rates on the possibility of credit access and the performance of manufacturing firms. Another important issue that this paper throws light upon is the importance of loan duration in influencing firm performance since it has a bearing on the cost of business operations. In addition, the study findings will assist manufacturers by opening their eyes to alternative sources of finance and probably giving them a better chance of survival, growth and success in the global competitive corporate setting.

The reminder of the paper is structured as follows. The preceding section concentrated on the background and motivation of the paper. Section 2 presents the literature and Section 3 gives the theoretical framework and the estimation strategy. Section 4 presents a discussion of the main findings while Section 5 concludes the paper and with implications for policy.

\section{Related Literature}

Literature presents several plausible theoretical and empirical underpinnings of the impact of credit constraint on firm performance and growth. Several authors present the view that credit constraint a key limiting factor to firm productivity and growth (Binks \& Ennew, 1996; Oliveira \& Fortunato, 2006; Rajan \& Zingales (1998) and Demirgüç-Kunt \& Maksimovic, 1998; Ojha et al., 2010; Winker, 1999; Beck et al. 2005). Authors like Ojha et al. (2010) and Winker (1999) show that financially constrained firms find it hard to invest in fixed capital and also lack the capabilities to innovate. In the same line of argument, Ayyagari et al. (2007) observe that enterprises innovate at a faster rate if they have access to external financing. Other authors (Hyytinen \& Toivanen, 2005; Ughetto, 2008; Canepa \& Stoneman, 2008; Ojah et al., 2010) note that limited access to external finance negatively affect small firms' decision to invest in fixed capital and research and development, which subsequently limit their growth, innovativeness and performance.

In addition, literature indicates that effect of financial constraint on firm growth varies across firms of different sizes and that the effect of financial constraint is stronger for smaller firms than large firms (Beck, 2007; Angelini \& Generale, 2008; Kuntchev et al., 2012; Weder, 2005; Carpenter \& Peterson, 2002; Oliveira \& Fortunato, 2006) and Kumar \& Francisco, 2005; Beck et al., 2005; Kuntchev et al., 2012). Similarly, Laeven (2003) shows that financial liberalisation reduces credit constraints for small firms and increases financial accessibility for large firms. Additionally, Carpenter \& Peterson (2002) show that lack of access to external 
financing by small firms and over dependence on internal finance and small borrowings from family/friends/informal sources greatly hinder firm productivity and growth. It has been documented that access to external financing promotes new entry of small firms to take advantage of growth opportunities in the expanding sectors and helps small firms to compete with large firms on a more levelled ground in business (Aghion et al., 2007; Becker \& Greenberg, 2005). Also, Cabral \& Mata (2003) find that finance constraints leads to firm size skewedness towards small firms and they conclude that when financing constraints are eliminated, small firms grow to their optimal size giving rise to a more symmetric distribution of firm sizes in the economy.

The reviewed literature presents several plausible theoretical and empirical underpinnings of the impact of credit constraint on firm performance. Tucker et al. (2003) note that information asymmetry problem is even more pronounced for small compared to their large counterparts since the former are not financially sophisticated meaning that at times they lack records to show the financial inflows and outflows. Thus, new start-up businesses may be unable to provide evidence of a good financial performance track record, whereas banks in particular rely on past financial performance as an indicator of the future profitability of projects. Other small firm financing problems relate to the characteristics of the firm itself and the attitude and objectives of the owner/manager such as their diversity, their inability to provide strong collateral, and stage of development effects. Owing to the lack of business experience of many small owner firms and the managers in the early years of the business, their business risk may be more significant than for larger firms. Small firms generally have no valuable collateral and have smaller financial reserves to draw on in times of crisis and are also relatively highly geared compared to larger firms due to the difficulty and expense of attracting new equity finance. Thus, such firms are characterized not only by higher business risk but also higher financial distress risk. Small firm financing, then, will typically be a heavily secured debt, with few incidences of external risk capital contribution (Cruickshank, 2000). Ogujiuba et al. (2004) show that equity component of external finance gives the financier the right of ownership in the business and as such may not require collateral since the equity participant will be part of the management of the business. It is worthy to note that whereas previous studies have addressed the issue of credit constraint and firm performance, none of the studies have considered the issue of loan duration as an alternative measure of credit constraint. Our study takes on this issue and hence represents a real value addition in this area of literature.

\section{Data and Methodology}

\subsection{Data}

The study uses the World Bank's Enterprise Surveys (2006) for Uganda, Kenya, Tanzania, Rwanda and Burundi. The World Bank's Enterprise Surveys collect data from key manufacturing and service sectors in every region of the world. The Surveys use standardized survey instruments and a uniform sampling methodology to minimize measurement error and to yield data that are comparable across the world's economies. The data set provides all the variables required for both descriptive and quantitative analyses of this study. Over $90 \%$ of the questions objectively ascertain characteristics of a country's business environment. The remaining questions assess the survey respondents' opinions on what are the obstacles to firm growth and performance. To researcher's knowledge, this is the only recent representative data set of firms that includes such information required for this study. This micro-econometric study is based on a sample of 1522 manufacturing firms; 307, 781, 102, 59 and 273 for Uganda, Kenya, Rwanda, Burundi and Tanzania respectively (Note 1).

\subsection{Analytical Techniques}

This study used both qualitative/descriptive and quantitative statistical techniques to analyze the World Bank Enterprise Survey (2006) for the East African countries; Uganda, Tanzania, Kenya, Rwanda, and Burundi using the Stata software. The descriptive analysis entailed the use of cross-tabulations where we generated the average percentages of firms and by key background characteristics in order to draw insights on the interactions between different characteristics. Specifically, we picked the key firm characteristics pertinent to the study (credit status and export status) and we cross-tabulated it with other background characteristics of firms.

The quantitative analysis entailed the use of two different methodologies; one for factors influencing credit access and the other analyzing the relationship between credit constraint and firm performance. We employed a simple probit in order to analyse the factors that are more likely to influence a firm's decision to obtain a loan. The dependent variable wad constructed as equal to one if a firm obtained a loan and zero otherwise. However, a simple probit model alone is a weak technique in this scenario because it does not harness all the information available to the econometrician, such as the extent or the degree of use (intensity) of credit by firms with banking credit. To solve this problem, we employed a maximum likelihood Tobit model during our analysis. The dependent variable in this case is the intensity of use of credit calculated as the share of banking credit in total 
credit. The model can be described as follows. For firm $i$, we consider the standard Tobit model (Tobin, 1958) expressed as:

$$
y_{i j}^{*}=X_{i j} \beta_{w}+\varepsilon_{i j}, \text { for } i=1 \ldots . . n \text {, and } j=1 \ldots 5
$$

From Equation 1, $y_{i j}^{* *}$ is a latent variable which satisfies the properties of the linear model. That is, it is a binary variable equal to 1 if the $i^{\text {th }}$ firm in country $j$ got banking credit and is equal to zero otherwise. This response is determined by the latent variable $y_{i}^{*}$. In order to parametrically estimate the model, $X_{i j}$ is the set of exogenous (independent) explanatory variables, $\beta$ is a vector of parameters to be estimated and $\varepsilon_{i j}$ is the error term normally distributed with mean zero and constant variance. We estimated equation 1 using a a simple probit model and in addition we employed a more rigorous Tobit model that considers the degree of intensity of loan utilization.

Additionally, we defined loan accessibility as a situation in which a firm applies for a loan and receives it. On the other hand, a credit constrained firm is one that applies for a loan and the application is rejected or that firm that did not apply at all. As a result of these two scenerios, we employed a two step maximum likelihood probit model that controls for the possible sample selection bais that exists between access to credit and demand for credit. In the first step of the analysis (model 2) we analyse the probability of having demanded for a bank loan and in the second step of the analysis (model 3), we estimate the probability estimate the probability of accessing or actually having a bank loan.

Model 2 can be viewed as the demand for credit and model 3 as the supply for credit.

$$
\begin{array}{cc}
\text { Credit } & D_{i j}=\alpha+\beta \text { firmcharacteristics }_{i j}+\beta \text { finvest }_{i j}+v_{i j} \\
\text { Credit } & S_{i j}=\alpha+\beta \text { firmcharacteristics } \\
i j & +\beta \text { finvest }_{i j}+e_{i j}
\end{array}
$$

From Equation 2 and 3, the firms' characteristics (which explain both models) are firm size, region, sector, ownership, managers' education, capacity utilization, age, export status, legal status, among others.

Another fundamental question addressed in our study is what is the effect of the credit constraint on manufacturing firms' performance in the EAC? We considered three main variables measuring the extent of the credit constraint. We considered a dichotomous variable equal to 1 if a firm had access to credit and zero if a firm is credit constrained or in other words has no access to credit. We also considered the annual interest rates in order to capture the cost of borrowing. We finally used loan duration in months to capture the period in which the firm can utilize the borrowed funds before the pay-back period. We hypothesized that the shorter the period the more beneficial the loan becomes to the firm. The higher the cost of borrowing, the greater the credit constraint. In order to estimate the effect of the credit constraint on firm performance, we considered a simple regression of the form:

$$
P_{i j}=\alpha+\gamma c_{i j}+X_{i j} \beta+v_{i j}
$$

From Equation 9, $P_{i j}$ denotes alternative measures of firm performance (sales and value added) of a typical firm $i$; $c_{i j}$ denotes whether the firm $i$ in country $j$ has banking credit $\left(c_{i j}=1\right)$ and zero otherwise $\left(c_{i j}=0\right)$. Alternatively, $c_{i j}$ would also represent a continuous variable such as the annual interest rate and the loan duration in months. $X_{i j}$ denotes observable characteristics of the same firm $i$ in country $j$. Here $v_{i j}$ indicates random, unobserved heterogeneity. We estimated equation 3 using a simple OLS to examine the potential impact of access to credit on firm performance controlling for other covariates. Our measures of firm performance are sales and value added. It is argued that credit access/constraint affects the performance of firms along with other firm-level characteristics aforementioned.

\section{Results}

\subsection{Descriptive Evidence}

We started our analysis with some descriptive evidence presented in form of cross-tabulations indicating the average share of manufacturing firms following key firm characteristics. The descriptive analysis is to be indicative of the scenario facing manufacturing firms and hence helps to lay a firm foundation for the regression based empirical findings. Table 1 shows the average percentage share of firms by background characteristics. 
Table 1. Average percentage share of firms by background characteristics

\begin{tabular}{|c|c|c|c|c|c|}
\hline Variable & All firms & Exporters & Non-exporters & obtained loan & obtained no loan \\
\hline \multicolumn{6}{|c|}{ Business constraints rated as very severe obstacles by manufacturing firms } \\
\hline Tax rate & 21 & 21 & 20 & 21 & 20 \\
\hline Access to land & 5 & 2 & 6 & 3 & 6 \\
\hline Tax administration & 9 & 12 & 9 & 12 & 8 \\
\hline Telecommunication & 4 & 7 & 3 & 5 & 4 \\
\hline Electricity & 43 & 43 & 43 & 39 & 45 \\
\hline Customs clearance & 8 & 15 & 7 & 14 & 5 \\
\hline Labor regulation & 1 & 2 & 1 & 2 & 1 \\
\hline Less educated workers & 3 & 5 & 2 & 4 & 2 \\
\hline Business licenses and permits & 7 & 8 & 7 & 8 & 7 \\
\hline Access to finance & 25 & 11 & 28 & 18 & 28 \\
\hline Political instabilities & 10 & 10 & 10 & 12 & 9 \\
\hline Macroeconomic instability & 10 & 13 & 10 & 10 & 10 \\
\hline Corruption & 15 & 17 & 14 & 18 & 13 \\
\hline \multicolumn{6}{|c|}{ Other firm characteristics } \\
\hline Full time workers & 27 & 74 & 19 & 39 & 22 \\
\hline Production workers & 62 & 188 & 30 & 101 & 40 \\
\hline Non production workers & 18 & 43 & 11 & 29 & 11 \\
\hline Female production workers & 26 & 75 & 9 & 31 & 22 \\
\hline Female non-production workers & 7 & 12 & 5 & 9 & 5 \\
\hline Skilled production workers & 33 & 92 & 18 & 56 & 20 \\
\hline Unskilled production workers & 39 & 11 & 18 & 56 & 28 \\
\hline Capacity & 71 & 71 & 71 & 70 & 72 \\
\hline Firm age & 14 & 24 & 12 & 18 & 12 \\
\hline Email use: No & 57 & 10 & 65 & 38 & 65 \\
\hline Yes & 43 & 90 & 35 & 62 & 35 \\
\hline Experience of the manager in years & 12 & 16 & 11 & 13 & 11 \\
\hline Firm size: Small & 54 & 12 & 63 & 31 & 65 \\
\hline Medium & 31 & 36 & 30 & 37 & 28 \\
\hline Large & 15 & 52 & 7 & 32 & 7 \\
\hline Sector: Food & 25 & 25 & 25 & 28 & 23 \\
\hline Textiles and Garments & 14 & 17 & 14 & 13 & 15 \\
\hline Machinery and Chemicals & 12 & 19 & 10 & 14 & 10 \\
\hline Wood and Furniture & 15 & 7 & 17 & 8 & 18 \\
\hline Metal & 34 & 32 & 35 & 37 & 33 \\
\hline Legal status: publicly listed company & 1 & 3 & 1 & 1 & 1 \\
\hline Privately held limited company & 44 & 81 & 37 & 63 & 36 \\
\hline Sole proprietorship & 38 & 9 & 44 & 23 & 45 \\
\hline Partnership & 15 & 4 & 17 & 12 & 17 \\
\hline Other & 1 & 2 & 1 & 1 & 1 \\
\hline Obtained a Loan : Yes & 32 & 60 & 27 & & \\
\hline No & 68 & 40 & 73 & & \\
\hline Non-exporter & 84 & & & 70 & 91 \\
\hline Exporter & 16 & & & 30 & 9 \\
\hline Number of firms & 1522 & 243 & 1279 & 491 & 1031 \\
\hline
\end{tabular}

Source: Own calculation from World Bank Enterprise Surveys for Uganda, Kenya, Tanzania, Rwanda, and Burundi; 2006.

Considering the business constraints (Table 1) that were rated as very severe by manufacturing firms, overall, electricity or power outages ranks highest amongst all constraints and across different firm categorizations; export status and credit status. Fourty three percent (43\%) of all manufacturing firms in the East African Community (EAC) ranked electricity as the most severe constraint of doing business in the region. This average percentage share remains highest, compared to all other business constraints, even after we categorize firms into exporters, non-exporters, those that obtained a loan and those that did not obtain a loan. Fourty three percent (43\%) of exporting and non-exporting firms reported electricity as a very severe business constraint respectively. Thirty nine percent (39\%) and $45 \%$ of firms that obtained a loan and those which did not obtain a loan reported electricity as a very severe business constraint respectively. These preliminary descriptive findings suggest that electricity outages and probably the cost per unit is one of the most teething constraints to manufacturers in the EAC. Therefore the governments in the region and the key stakeholders (especially) donors must take keen interest into solving the electricity problem as a means of improving the microeconomic environment.

Table 1 shows that overall manufacturing firms ranked access to finance as the second most severe business constraint in the EAC after electricity. The non-exporting firms and firms that did not obtain loans also ranked access to finance as their second most pressing business constraint in doing business. As expected, access to finance was ranked fourth by firms that obatined loans. The implication of this finding is that the firms that can 
afford loans are in a position to invest into alternative sources of power and hence find that electricty is not a severe business constarint. Governments in the region and other stakeholders should design a set of policies to ensure increased penetration of loans amongst business firms in order to realize high capital intensity and

Table 1 further shows that tax rate is ranked third most severe business constraints by manufacturing firms in the EAC. This constraint is manifested in terms of highly volatile and very high tax rates. Twenty one percent (21\%) of all manufacturing firms in the region ranked it as the third most pressing business constraint. Also $21 \%$ of exporters and firms that obtained loans ranked tax rate as their second most pressing business constraint while $20 \%$ the non-exporters and firms that did not obtain loans ranked it as third. Hence governments in the region ought to adopt a more predictable tax rate regimes which are affordable by the investors in order to create a conducive environment for them. It is also important to note that corruption was reported by $15 \%$ of firms in the region as the fourth severe constraint that affects the smooth operation of business firms in the region. At the same time, exporting firms and firms that obtained loans ranked corruption as their third most pressing business constraint in doing business while $14 \%$ of non-exporters and firms that did not obtain loans ranked corruption as their fourth most pressing constraint. Governments in the region ought to develop a political will with a strong stance to fight corruption in order to create a conducive atmosphere for business operations. Macroeconomic instability was ranked fifth among the business constraint by about $10 \%$ of the sampled firms in the region. Similarly, $10 \%$ of East African exporting firms and the firms which did not get loans ranked macroeconomic instability in terms of high inflation rates as the fifth most pressing business constraints. Governments in the region should pursue prudent macroeconomic policies which aim at a single digit inflation rate and with accelerated economic growth rate.

Table 1 does not show any significant difference in capacity utilisation among exporters and non-exporters and firms that obtained loans and those that did not obtain loans. In regard to firms age, on average, all manufacturing firms in the region have been in operation for 14 years while the exporting firms are 10 years older than their counterparts and firms that obtained a loan are 5 years olders than their counterparts. This might imply that it takes some time for firms to penetrate into the global trade arena and slightly more time for them to penetrate into the financial markets. With globalisation and economic integration, our study further analyses the use of emails by firms. Table 1 reveals that on the overall $43 \%$ of EAC firms use internet while $57 \%$ do not use internet. In case of exporting firms $88 \%$ of firms use email compared to $65 \%$ of non-exporting firms. As far as credit access is concerned, $62 \%$ of firms with loans use emails compared to only $35 \%$ of firms with no loans. This issue points to the issue of affordability to install internet and to pay the monthly charges. There might also be a possibility of technology iliteracy, particularly among the older self entrepreneurs, especially given the fast declining cost of internet in the region.

In addition, our analysis looks at managers' experience at the foreign firm cross-tabulated with key characteristics of interest to this paper. On average, managers of manufacturing firms in the EAC have about 12 years of experience at a foreign firm before starting to manage the current enterprise. On the other hand, managers of exporting firms are 6 years more experienced compared to their non-exporting counterparts. Furthermore, managers of firms that obtained a loan are 3 years more experienced compared to their counterparts that did not obtain a loan. Our findings clearly articulate the fact that having more experience before managing the current enterprise leads to better performance and hence the ability to penetrate into global markets and into the financial markets for borrowing.

Analysis of firms by size reveals that the majority of manufacturing firms within the EAC are small firms constituting on average $54 \%$ of the samped firms. The average percentage of manufacturing firms drops drastically when we observe the average percentages on medium and large firms. Thirty one percent $31 \%$ of firms within the EAC are medium firms while only $15 \%$ are large firms. This finding implies that the business capital in the EAC has not yet grown to admirable levels. In terms of export status, about $52 \%$ of exporting firms are large compared to only $7 \%$ of non-exporting firms while $34 \%$ of exporting firms are medium firms compred to only $30 \%$ of non-exporting firms. These findings are in line with earlier expectations that exporting firms are larger and outperform their non-exporting counterparts. In terms of access to credit, $37 \%$ of medium firms obtained credit compared $28 \%$ of firms that did not obtain loans. It is evident that very few exporting firms (12\%) compared to the non-exporting firms (63\%) are small firms and at the same time only about $31 \%$ small firms obtained loans compared to $65 \%$ firms that did not obtain loans.

Further analysis of firm charateristics in terms of sectors indicate that metal fabrications subsector constitutes the highest average percentage of firms (34\%), followed by the food processing subsector (25\%), wood and furniture $(15 \%)$, Textile and Garments (14\%) and the subsector with the lowest share is Machinery and Chemicals (12\%). In terms of export status, most exporting firms are in the Metal fabrications subsector (32\%), followed by Food 
processing (25\%), machinery and chemicals (19\%), textile and garments (17\%) and Wood and Furniture (7\%). Additionally, non-exporting firms are dominated by firms in the metal subsector $(35 \%)$ followed by food processing (25\%), Wood and Furniture (17\%) and the least is Machinery and Chemicals (10\%). In terms of firms' access to credit captured by firms that obtained loans and those which did not obtain loans, Table 1 shows that in the Metal fabrications subsector $37 \%$ of firms obtined loans compared to $33 \%$ of firms which did not, followed by food processing with $28 \%$ of firms that obtained loans compared to $24 \%$ of firms that did not obtain loans, for Machinery and Chemicals firms $14 \%$ obtained loans compared to $10 \%$ of firms that did not, in the Textile and Garments, $13 \%$ obtained loans compared $15 \%$ of firms that did not, while in Wood and Furniture only $8 \%$ of firms obtained loans compared to $18 \%$ which did not obtain loans. This differentail access of manufacturing firms to credit implies that givernment attention should also be specifically targeting more those sectors that are more credit constrained, in this case the Wood and Furniture as well as the Textiles and Garments subsectors.

Finally, the analysis of firms by their legal status reveals interesting findings. First, the manufacturing sector is dominated by privately limited companies (44\%), followed by sole propretorship (38\%), partnership (15\%) and the public listed companies are about $1 \%$ given the privatisation of most state enterprises in the region. By export status, $82 \%$ of the privately held limited companies are exporting firms compared to only $37 \%$ non-exporting firms. However, sole proprietorship (44\%) dominate the non-exporting firms followed by the privately held limited companies (37\%). In terms financial access, $63 \%$ of privately held limited companies obtained loans while $35 \%$ did not. However, publicly listed limited companies had the lowest share of firms that obtained loans in the region.

\subsection{Empirical Results}

\subsubsection{Factors Influencing Firm Access to Credit Facilities}

We used maximum likelihood probit model to estimate the factors influencing access to credit amongst manufacturing firms in the EAC. Our dependent variable equals to one if a firm had a loan and zero otherwise. The key independent variables of interest are the measures of a firm's performance; we used firm sales and value added and we included other controls such as capital stock, export status, sector, and capacity utilization among others.

Table 2. Factors influencing firm access to credit (marginal effects after a probit analysis)

\begin{tabular}{|c|c|c|}
\hline Variables & Model (1) & Model (2) \\
\hline Sales & $0.0834 * * *(0.000)$ & \\
\hline Capital stock & $-0.0015 \quad(0.7480)$ & $-0.0186 \quad(0.126)$ \\
\hline Export status & $0.135 * * * \quad(0.000)$ & $0.137 * * *(0.009)$ \\
\hline Wages & $-0.102 * * * \quad(0.000)$ & $-0.0822 * * *(0.000)$ \\
\hline Capacity utilization & $-0.0950 \quad(0.116)$ & $-0.0099 \quad(0.212)$ \\
\hline Firm age & $-0.0390 \quad(0.133)$ & $-0.0375 \quad(0.147)$ \\
\hline No use of email & $-0.108 * * \quad(0.014)$ & $-0.110 * *(0.012)$ \\
\hline Manager's experience & $0.0546 \quad(0.135)$ & $0.0484 \quad(0.184)$ \\
\hline Manager's experience squared & $-0.0015 \quad(0.819)$ & $-0.0002 \quad(0.974)$ \\
\hline Sector: Textiles and Garments & -0.0698 & $-0.0061 \quad(0.361)$ \\
\hline Machinery and Chemicals & $(0.321)$ & $0.0532 \quad(0.424)$ \\
\hline Wood and Furniture & -0.0054 & $-0.114 * *(0.023)$ \\
\hline Metal s & -0.0323 & $-0.0362 \quad(0.442)$ \\
\hline Size: Medium & $0.184 * * *(0.000)$ & $0.189 * * *(0.000)$ \\
\hline Large & $0.499 * * *(0.000)$ & $0.513 * * *(0.000)$ \\
\hline Value added & & $0.0609 * * *(0.002)$ \\
\hline Region & Yes & Yes \\
\hline Legal status & Yes & Yes \\
\hline Ownership & Yes & Yes \\
\hline Observations & 794 & 793 \\
\hline Number of countries & 5 & 5 \\
\hline Log likelihood & -384.60134 & -386.66701 \\
\hline Pseudo Square & 0.1996 & 0.1933 \\
\hline
\end{tabular}

$\mathrm{p}$-value in parentheses; $* * * \mathrm{p}<0.01, * * \mathrm{p}<0.05, * \mathrm{p}<0.1$.

The analysis reveals that firm performance has a bearing on the probability of a firm's access to credit. An increase in the sales of the firm by $1 \%$ increases the probability of access to credit by $0.08 \%$ and this relationship is statistically significant at $1 \%$ level. Similarly, an increase in the firm's value added by $1 \%$ increases the probability of a firm's access to credit by $0.06 \%$ and this relationship is highly statistically significant at $1 \%$ level. Therefore, government policy should be focused against the business constraints that impede the superior 
performance of business firms if firm growth through credit accessibility is to be realized. During our descriptive analysis (Table 1), we identified electricity and the most severe business constraint faced by firms in the region, access to finance comes second, and high and volatile tax rates come third. If the governments in the region focus on these in their order of severity, there will be a bright future for manufacturers in the region through borrowing to accumulate machinery, land, and hiring highly qualified workers.

Capital stock of the firms is revealed significant in influencing the probability of a firm's access to credit. An increase in a firm's capital stock by one unit reduces the probability of access to credit by $0.02 \%$ and this relationship is significant at $10 \%$ level. Whereas this result may appear counterintuitive, there is a convincing explanation that can be argued out logically. That is, a firm with a higher capital stock is believed to have accumulated the necessary machinery, plants, and land and hence may not need to borrow money. Instead such a firm has the capability to raise money internally by sale of shares and retaining part of the profits for investment purposes. A firm with lower capital stock on the other hand, may not have the capacity to mobilize own resources without borrowing. Hence governments in the EAC should target small firms to make it cheaper for them to access credit since it is these firms that are at an extreme disadvantage of accumulating capital goods from own savings (Note 2). In addition, a firm that pays higher wages is less likely to borrow money compared to counterparts paying lower wages. An increase in the wages paid by the firm by 1 unit decreases the probability of access to credit by $0.08-0.1 \%$ and this relationship is highly statistically significant. Whereas this may also appear to be counterintuitive, on the other hand, it can be argued out logically. Firms that pay higher wages are those that have also accumulated enough capital and have also consolidated their position in the market and hence can afford to mobilize own resources without borrowing.

As expected, export status of the firm significantly influences the probability of accessing credit facilities. Being an exporter, compared to counterparts that are non-exporters, increases the probability of access to credit by approximately $14 \%$ points. This can be attributed to the sophisticated nature of activities that exporters are supposed to do which may be well beyond their savings. Some of the these activities are preconditions for exporting set in the global trading arena and in many of the cases require enormous investment in terms of machinery and equipment which can only be done by using borrowed funds. Additionally, exporters face a number of problems like operating in a distant market, acquiring market information and dealing with a different legal and regulatory framework. All these require a sound financial stand for exporters which may go beyond own savings. Governments in the EAC region should advocate for easy loans for exporters so that it is cheaper for them to carry out their activities successfully.

Furthermore, our findings articulate the importance of firm size in influencing the probability of credit access. Being a medium firm, compared to counterparts that are small firms, increases the probability of credit access by approximately $19 \%$. Additionally, being a large firm, compared to counterparts that are small firms increases the probability of credit access by $50-51 \%$. This can be attributed to the fact that large firms have the required collateral which financial institutions need as a precondition for credit disbursement. Additionally large firms have the capacity to service the loan without exerting a lot of stress on other activities of the firm. Therefore, governments in the EAC can put in place a conducive microeconomic environment that can enhance the expansion of business firms. For example, governments should strive to solve the business constraints we identified earlier as being very severe; electricity, tax rates, access to finance and corruption.

\subsubsection{Credit Access and Firm Performance in the EAC}

We estimated various models relating credit access and firm performance in the EAC. Our key dependent variables are firm sales and value added and yet the key independent variable are credit access, annual interest rate and loan duration in months and other control variables. As expected, credit access is significantly related to firm performance. Firms having access to credit increase the level of firm performance by 0.2 to 0.3 percentage points and this relationship is statistically significant at one percent level (Table 3). 
Table 3. Credit access and firm performance (Pooled OLS)

\begin{tabular}{|c|c|c|c|c|c|c|}
\hline Variables & Model (1) & Model (2) & Model (3) & Model (4) & Model (5) & Model (6) \\
\hline Loan & $0.306^{* * *}(0.002)$ & $0.239^{* * *}(0.001)$ & & & & \\
\hline Capital stock & $0.155^{* * *}(0.000)$ & $0.149^{* * *}(0.000)$ & $0.164^{* * *}(0.00)$ & $0.1800^{* * *}(0.000)$ & $0.153^{* * * *}(0.001)$ & $0.164^{* * * *}(0.000)$ \\
\hline Export status & $0.114 \quad(0.217)$ & $0.137 \quad(0.149)$ & $0.0641 \quad(0.668)$ & $-0.0065 \quad(0.965)$ & $0.0886 \quad(0.547)$ & $0.0208 \quad(0.887)$ \\
\hline Wages & $0.789^{* * *}(0.000)$ & $0.783^{* * *}(0.000)$ & $0.842^{* * *}(0.000)$ & $0.838^{* * *}(0.000)$ & $0.839^{* * * *}(0.000)$ & $0.843^{* * *}(0.000)$ \\
\hline Labor force & $0.111 * * *(0.003)$ & $0.111^{* * *}(0.004)$ & $-0.0191(0.778)$ & $-0.0027 \quad(0.967)$ & $0.00908(0.890)$ & $0.0266 \quad(0.692)$ \\
\hline $\begin{array}{l}\text { Capacity } \\
\text { utilization }\end{array}$ & $0.204^{* *} \quad(0.047)$ & $0.356^{* * *}(0.001)$ & $-0.0247(0.909)$ & $-0.0618 \quad(0.772)$ & $0.0233 \quad(0.913)$ & $-0.0018(0.993)$ \\
\hline Firm age & & $0.0162 \quad(0.723)$ & $0.1150 \quad(0.226)$ & $0.0750 \quad(0.420)$ & 0.1490 & $0.1010 \quad(0.275)$ \\
\hline No use of email & $-0.125 \quad(0.101)$ & $-0.129 \quad(0.100)$ & $0.0665 \quad(0.689)$ & $-0.0048 \quad(0.976)$ & 0.0429 & $-0.0014(0.993)$ \\
\hline $\begin{array}{l}\text { Manager's } \\
\text { experience }\end{array}$ & $-0.169^{* * *}(0.002)$ & $-0.148^{* *}(0.017)$ & $-0.0756 \quad(0.613)$ & $-0.1270 \quad(0.389)$ & $-0.0916 \quad(0.535)$ & $-0.1260(0.385)$ \\
\hline $\begin{array}{l}\text { Manager's } \\
\text { experience } \\
\text { square }\end{array}$ & $0.0003^{* *}(0.027)$ & $0.0002^{*}(0.091)$ & $0.0001 \quad(0.724)$ & 0.0001 & $0.0009(0.744)$ & $0.0007 \quad(0.798)$ \\
\hline Size: Medium & $0.0788 \quad(0.374)$ & $0.0624 \quad(0.493)$ & $-0.0805(0.670)$ & -0.0208 & $0.0173 \quad(0.923)$ & $0.0071 \quad(0.969)$ \\
\hline Large & $0.2270 \quad(0.110)$ & $0.0582 \quad(0.690)$ & $0.0986 \quad(0.691)$ & $-0.0005 \quad(0.998)$ & $0.2120 \quad(0.378)$ & $0.0024 \quad(0.992)$ \\
\hline $\begin{array}{l}\text { Sector : } \\
\text { Textiles and } \\
\text { Garments }\end{array}$ & $-0.404^{* * *}(0.000)$ & $-0.211^{* *}(0.021)$ & $-0.722^{* * *}(0.000)$ & $-0.474^{* * *}(0.006)$ & $-0.699^{* * *}(0.001)$ & $-0.488^{* * *}(0.005)$ \\
\hline $\begin{array}{l}\text { Machinery and } \\
\text { Chemicals }\end{array}$ & $-0.0587(0.618)$ & $0.0874 \quad(0.471)$ & $-0.2830(0.192)$ & $-0.0450 \quad(0.831)$ & $-0.2690 \quad(0.203)$ & $-0.1170 \quad(0.580)$ \\
\hline $\begin{array}{l}\text { Wood and } \\
\text { Furniture }\end{array}$ & $-0.176^{* *} \quad(0.047)$ & $-0.0783 \quad(0.392)$ & -0.031951 & -0.2500 & -0.030702 & $-0.2830 \quad(0.174)$ \\
\hline Metal s & $0.0051(0.952)$ & $0.0425 \quad(0.623)$ & $-0.2700 \quad(107)$ & -0.1160 & -0.02028 & $-0.1940 \quad(0.241)$ \\
\hline $\begin{array}{l}\text { Ownership: } \\
\text { African }\end{array}$ & $0.150 \quad(0.146)$ & $0.132 \quad(0.216)$ & $0.389^{* *}(0.028)$ & $(0.233)$ & $0.4520^{* * *}(0.010)$ & $0.2270 \quad(0.189)$ \\
\hline Indian & $0.0251 \quad(0.823)$ & $0.051 \quad(0.661)$ & $0.258 \quad(0.169)$ & $0.1310 \quad(0.475)$ & $0.2630 \quad(0.158)$ & $0.1820 \quad(0.319)$ \\
\hline Europe & $(0.497)$ & $0.186 \quad(0.240)$ & $0.688 * *(0.026)$ & $0.654 * *(0.032)$ & $0.6400 * * \quad(0.035)$ & $0.5770 *(0.054)$ \\
\hline $\begin{array}{l}\text { Interest rate } \\
\text { annual }\end{array}$ & & & $-0.327 * *(0.040)$ & $-0.321 * *(0.041)$ & & \\
\hline $\begin{array}{l}\text { Loan duration } \\
\text { in months }\end{array}$ & & & & & $0.1440 *(0.086)$ & $0.217 * * *(0.009)$ \\
\hline Constant & $1.549 * \quad(0.054)$ & $0.510 \quad(0.538)$ & $1.2040 \quad(0.472)$ & $(0.465)$ & $-0.2200 \quad(0.884)$ & $-0.8950 \quad(0.568)$ \\
\hline Regions & Yes & Yes & Yes & Yes & Yes & Yes \\
\hline Legal status & Yes & Yes & Yes & Yes & Yes & Yes \\
\hline Observations & 781 & 777 & 223 & 222 & 223 & 222 \\
\hline $\begin{array}{l}\text { Number of } \\
\text { countries }\end{array}$ & 5 & 5 & 5 & 5 & 5 & 5 \\
\hline R-squared & 0.854 & 0.838 & 0.888 & 0.89 & 0.886 & 0.891 \\
\hline
\end{tabular}

P-value in parentheses; ${ }^{* * *} \mathrm{p}<0.01,{ }^{* *} \mathrm{p}<0.05,{ }^{*} \mathrm{p}<0.1$.

In the same line of argument an increase in the annual interest rate by one percent reduces firm performance by 0.3 percentage points and this relationship is statistically significant at $5 \%$ level. Additionally, an increase in the loan duration by one month increases firm performance by 0.1 to 0.2 percentage points and this relationship is highly statistically significant. The findings clearly articulate the fact that access to credit is beneficial to firm performance yet the cost of credit has a dampening effect on firm performance. Similarly, the longer the duration of the loan the higher the scope for firms to benefit by utilizing the loan funds and also paying back smaller bits of money spread over a long period without stressing other business activities. Therefore, governments in the region through central banks should advocate for more friendly credit conditions in terms of the preconditions like collateral and the cost of borrowing in terms of interest rate as well as the duration of the loan that ensures a fairly long repayment period.

As expected the capital stock of the firm is significantly associated with firm performance. An increase in the stock of capital by one unit increases firm performance by 0.15 to 0.18 percentage points. Given that developing countries are at an extreme disadvantage in the production of capital goods, governments in the region should design policies that can support manufacturing firms in their attempt to accumulate enough capital. Since most of the machinery and plants used in the production processes are imported, governments should make it cheaper for firms to import capital goods by exempting them from taxation or by imposing a modest tax rate. Additionally, much of the required capital in terms of machinery, land and buildings are too expensive to acquire using own savings, hence business firms should be assisted to get access to cheap and easy credit which can facilitate quicker capital accumulation.

The findings indicate that an increase in the wage rate by one unit increases firm performance by approximately 0.8 percentage points. This finding fully supports the efficiency wage theory, which argues that highly paid workers are healthier and hence more productive. Government policy that can influence a minimum wage legislation can go a long way in improving firm productivity which is a pre-condition for fuelling economic 
growth at an aggregate level. Additionally, employment significantly influences firm performance. An increase in employment by one worker increases the level of firm performance by 0.1 percentage points and this relationship is statistically significant. However, this result should be treated with caution because the quality of the labour force in terms of education and health matters in influencing firm productivity. Therefore, governments in the region should target to influence higher institutions of learning to develop a curriculum that is driven by the skill demands of the private sector. Additionally, government should establish independent institutions that are relevant to the private sector skills gaps such that the graduates from such institutions can fit very well in the private sector production processes or activities.

The results indicate that an increase in capacity utilization by one unit increases the level of firm performance by 0.2 to 0.4 percentage points and this relationship is highly statistically significant. Therefore, governments in the region should create a conducive microeconomic environment that facilitate the full utilization of the installed capital of firms. Such problems as electricity outages, corruption, limited access to finance and high tax rates should be tackled by the governments as a matter of priority. As expected the years of experience of the manger at the foreign firm significantly influences the level of firm performance in our analysis. The level of the years of manager's experience reduce the level of performance by 0.15 to 0.17 percentage points yet the square of the years of manager's experience positively and significantly influence the level of firm performance. This relationship produces the expected statistically significant quadratic term on the years of the manger's experience.

The results indicate that a firm in textiles and garments compared to one in the food processing reduces the level of firm performance by 0.2 to 0.7 percentage points and this relationship is statistically significant at one percent level. A firm in the wood and furniture to compared to one in the food processing reduces the level of firm performance by 0.2 to 0.4 percentage points and this relationship is statistically significant at $5 \%$ level. A firm in the metal fabrications compared to one in the food processing reduces the level of firm performance by 0.3 percentage points and this relationship is statistically significant at $10 \%$ level. The findings also articulate the importance of the ownership of the firm in influencing firm performance. A firm owned by an African entrepreneur compared to one owned by the Middle Eastern increases the level of firm performance by 0.4 to 0.45 percentage points. Similarly a firm owned by a European entrepreneur compared to the one owned by a Middle Eastern increases the level of firm performance by 0.6 to 0.7 percentage points and this relationship is statistically significant at 5 percent level.

\subsubsection{Two Stage Probit Analysis Of Credit Access And Constraints}

Table 4 reveals further insights into the factors influencing access to credit by manufacturing firms in the East African Community. We use a two-step probit analysis in order to control for the selectivity bias, where highly productive firms are more likely to self-select themselves into the credit market. The first stage regressions show the demand for loans where we include all firms that applied for the loan whether they succeeded in accessing the loan or not. The second stage regressions indicate the supply of loans where we included only those firms that accessed the loan. 
Table 4. Two stage probit estimates for determinants of credit constraint in EAC

\begin{tabular}{|c|c|c|c|c|}
\hline Variables & First stage prob & Second stage & First stage prob & Second stage \\
\hline Sales & $0.251 * * *(0.002)$ & $0.708^{* * *}(0.001)$ & & \\
\hline Capital stock & $-0.027(0.0365)$ & $0.162 *(0.066)$ & $-0.0186(0.0364)$ & $0.146 *(0.0660)$ \\
\hline Export status & $0.402 * *(0.010)$ & $-0.0493(0.250)$ & $0.403 * *(0.015)$ & $-0.0096(0.248)$ \\
\hline Wages & $-0.331 * * *(0.001)$ & $0.0939(0.133)$ & $-0.288 * * *(0.002)$ & $0.0335(0.1350)$ \\
\hline Capacity utilisation & -0.078057 & $-0.712(0.3690)$ & $-0.469^{* *}(0.1790)$ & $-0.715(0.3660)$ \\
\hline Firm age & $-0.120(0.077)$ & $-0.0245(0.154)$ & $-0.117(0.076)$ & $-0.0151(0.153)$ \\
\hline Email & $0.385 * *(0.128)$ & $-0.0975(0.281)$ & $0.390 * *(0.128)$ & $-0.105(0.279)$ \\
\hline Manager's experience & $0.139(0.106)$ & $0.123(0.106)$ & & \\
\hline Manager's experience squared & $0.0001(0.0002)$ & $-0.0008(0.453)$ & & \\
\hline Textile and Garments & $0.0328(0.154)$ & -0.038003 & $-0.0293(0.152)$ & -0.041904 \\
\hline Machinery and Chemicals & $0.288(0.195)$ & $0.289(0.361)$ & $0.249(0.194)$ & $0.128(0.357)$ \\
\hline Wood and Furniture & -0.020724 & $0.0761(0.360)$ & $-0.183(0.157)$ & $-0.0001(0.361)$ \\
\hline Metals & $-0.0752(0.144)$ & $0.524(0.292)$ & $-0.0886(0.144)$ & $0.438(0.289)$ \\
\hline Medium firms & $0.591 * * *(0.000)$ & $0.0667(0.309)$ & $0.604 * * *(0.000)$ & $0.0153(0.307)$ \\
\hline Large firms & $1.257 * * *(0.000)$ & $-0.0086(0.548)$ & $1.305 * * *(0.000)$ & $0.0408(0.392)$ \\
\hline African & $-0.2660(0.175)$ & $-0.178(0.293)$ & $0.243(0.174)$ & $-0.260(0.289)$ \\
\hline Indian & $-0.0972(0.188)$ & -0.205641 & $-0.105(0.188)$ & -0.22866 \\
\hline Europe & $-0.2040(0.2570)$ & $-0.426(0.860)$ & $-0.194(0.2580)$ & $-0.447(0.4810)$ \\
\hline Value added & & & $0.202 * * *(0.059)$ & \\
\hline Constant & $1.798(1.112)$ & $3.806(2.184)$ & $2.097(1.104)$ & $4.303 *(2.155)$ \\
\hline Region & Yes & Yes & Yes & Yes \\
\hline Sectors & Yes & Yes & Yes & Yes \\
\hline $\mathrm{N}$ & 794 & 229 & 793 & 228 \\
\hline
\end{tabular}

Standard errors in parentheses ${ }^{*} \mathrm{p}<0.05,{ }^{* *} \mathrm{p}<0.01,{ }^{* * *} \mathrm{p}<0.001$.

Our first stage regressions are not any different from our earlier findings of the probit analysis in Table 4. The level of performance of the firms is revealed significant in influencing the probability of demand for credit in the East African manufacturing sector. An increase in the level of sales of the firm by one unit increases the probability of demand for credit by approximately $0.3 \%$. Similarly, an increase in the level of value added of the firms by one unit increases the probability of demand credit by $0.2 \%$. On the supply side, an increase in the level of sales by one unit increases the amount supplied of credit by 0.7 percentage points. This result might imply that highly efficient firms induce credit supply, that is, financial institutions supply more credit to above average performing firms compared to their counterparts. These results, just as in the previous analysis, clearly articulate the importance of firm performance in increasing the demand for credit. Therefore, governments in the EAC should design policy options that are intended eliminate hindrances in the microeconomic environment that may limit the good performance of business firms. In particular, governments should pay close attention to those business constraints that manufacturing firms rated as being very severe; electricity outages, access to finance, corruption, and macroeconomic instability among others.

The findings also reveal the importance of capital stock of manufacturing firms in influencing the amount of credit that business firms are likely to supply. An increase in capital stock by one unit increases the amount of credit that financial institutions are willing to offer by $0.03-0.16$ percentage points. This might imply that lending institutions prefer to lend money to business firms that are already successful compared to their counterparts that are in episodes of struggle to survive in the business environment. Government effort and policy aimed at helping struggling firms gain access to finances is long overdue for the case of the manufacturing firms in the EAC. Furthermore, our findings articulate the importance of export status in influencing the probability of demand for credit. Being an exporter, compared to non-exporting firms, increases the probability of demand for credit by 0.4 percent. This is in line with the argument that exporting firms are usually more productive and bigger than their non-exporting counterparts and hence is more likely to self-select themselves into the credit market. Government policy intended to eliminate or at least reduce the sunk cost which inhibit firms from breaking into the global trading area is therefore called for. Surprisingly, however, export status is not significant in influencing the supply of credit in the region.

The results further indicate that an increase in wages by one unit decreases the probability of demand for credit by approximately 0.3 percent. This result might imply that firms paying higher are those that are already mature, accumulated enough capital and have the capacity to mobiles resources through other channels other than borrowing. They may mobilize resources internally through the sale of shares or by using part of the profits made. Similarly, a firm with higher capacity utilization is less likely to demand for credit. An increase in capacity utilization by one unit reduces the probability of demand for credit by $0.4-0.7$ percent. This might imply that firms that have utilized much of their capacity might have limited need for further financing since the scope for 
expansion might have been exhausted.

Firms that use emails during their business operations are revealed to increase the probability of demand for credit. Firms that use an email, compared to counterparts that don't, increase the probability of credit demand by approximately 0.4 percent. These are firms that are usually more efficient and also connected to the global trading arena. As expected, and also in line with the previous analysis, firm size is revealed important in influencing the probability of demand for credit. Being a medium firm, compared to small firms, increases the probability of demand for credit by approximately 0.6 percent. Being a large firm, compared to small firms, increases the probability of credit by over 0.6 percent. Therefore, government effort that eliminates severe business constraints will lead to fast growth of firms and also enhance participation in the credit market.

\subsubsection{Analysis of Credit Constraint Using Tobit Model}

Table 5 below presents the Tobit models estimates of the determinants to credit access and credit constraints in the EAC region. In estimation the model is left censored at 0.2 and the right censoring is at 1 . Tobit model 1 estimated using 204 observations while Tobit model 2 is based on 202 observations. The likelihood ratio chi-square of 69.19 with a p-value of 0.0001 tells us that our model as a whole fits significantly better than an empty model (i.e., a model with no predictors).

Table 5. Tobit estimation of credit constraint faced by manufacturing firms in EAC

\begin{tabular}{|c|c|c|c|c|c|c|}
\hline Variables & Coeff. & & St Err & Coef. & & St.Err \\
\hline Loan duration & $0.046^{*}$ & & $(0.059)$ & $0.045^{*}$ & & $(0.019)$ \\
\hline Capital stock & 0.005 & & $(0.107)$ & 0.005 & & $(0.107)$ \\
\hline Export status & $0.008 * *$ & & $(0.024)$ & $0.002 *$ & & $(0.051)$ \\
\hline Fulltime workers & -0.007 & & $(0.015)$ & -0.007 & & $(0.145)$ \\
\hline Capacity utilisation & $-0.108^{*}$ & & $(0.048)$ & $-0.108 *$ & & $(0.071)$ \\
\hline Firm age & -0.037 & & $(0.022)$ & -0.034 & & $(0.211)$ \\
\hline Email & -0.032 & & $(0.137)$ & & & \\
\hline Manager's experience & -0.005 & & $(0.134)$ & -0.009 & & $(0.333)$ \\
\hline Manager's experience squared & 0.004 & & $(0.121)$ & 0.001 & & $(0.101)$ \\
\hline Medium firm & 0.012 & & $(0.143)$ & 0.009 & & $(0.410)$ \\
\hline Large firms & $0.073^{*}$ & & $(0.055)$ & -0.082 & & $(0.546)$ \\
\hline Private held limited company & $-0.428 * * *$ & & $(0.000)$ & $-0.430 * * *$ & & $(0.000)$ \\
\hline Sole proprietorship & $-0.387 * *$ & & $(0.012)$ & $-0.384 * *$ & & $(0.011)$ \\
\hline Partnership & $-0.287^{*}$ & & $(0.068)$ & $-0.290 *$ & & $(0.053)$ \\
\hline Indian & 0.064 & & $(0.134)$ & 0.061 & & $(0.232)$ \\
\hline Interest & & & & -0.035 & & $(0.107)$ \\
\hline Constant & $0.938 * * *$ & & $(0.002)$ & $0.920 * *$ & & $(0.014)$ \\
\hline Sector & & Yes & & & Yes & \\
\hline Region & & Yes & & & Yes & \\
\hline Sigma & $0.1810^{* * *}$ & & & $0.1820 * * *$ & & $(0.009)$ \\
\hline $\mathrm{N}$ & 204 & & & 204 & & \\
\hline
\end{tabular}

P-values in parentheses ${ }^{*} \mathrm{p}<0.05,{ }^{* *} \mathrm{p}<0.01,{ }^{* * *} \mathrm{p}<0.001$.

In the Table 5 we present the coefficients and their standard errors. The results indicate that for a one unit increase in loan duration by one month, there is a 0.046 point (sales model 1 ) and 0.045 point (value added model) increase in the predicted value of access to credit by manufacturing firms in the EAC region. Therefore, government efforts that ease access to credit for manufacturing firms will lead to fast growth of firms and also enhance participation in the credit market. In addition, a one unit increase in capacity utilization is associated with a 0.19 decrease in the predicted value of the firm sales and 0.15 decrease in the value added of the firms in the EAC. In this aspect governments in the EAC region should direct efforts that eliminate market barriers in order to enable firms to use up their installed capacity and hence promote industrial development.

The findings in Table 5 furtherarticulate the importance of export status in influencing the probability of demand for credit. Note that a firm being an exporter, compared to non-exporting firms, increases the probability of demand for credit by $0.01 \%$. This is in line with the argument that exporting firms are usually more productive and bigger than their non-exporting counterparts and hence is more likely to self-select themselves into the credit market. Therefore, governments in the EAC need to promte policy measures that are aimed at eliminating barriers to trade. Additionally, the predicted value of sales values is 46.14 points lower for Private held limited companies than publicly listed company in the region. Furthermore, Sole proprietorship and partnership firms' sales value are 0.39 and 0.38 points lower respectively than publicly listed company. In terms of value added, it is only private held limited companies that lower value added by 0.43 points compared to the publicly listed 
company in the region. Note that other forms of business organization also depict negative effects though not statistically significant. From this finding the key policy message is that governments in the EAC should harmonize commercial laws and ease business registration as a means to promote capital markets.

\section{Conclusion and Policy Implications}

This study set out to investigate the factors influencing manufacturing firms' access to credit and the effect of credit constraints on firm performance in the East African Community. We used the most current enterprise survey data sets of the World Bank (2006) for Uganda, Kenya, Tanzania, Rwanda, and Burundi. We employed simple probit, simple OLS, tobit, and a two-step probit models. Amongst the top five business constraints, electricity outages and costs were found to be the most severe business constraints followed by access to finance, high and volatile tax rates, corruption, and macroeconomic instability. The majority of firms within the EAC are credit constrained because the average percentage share of the best performing sector (metal fabrications) is also quite low at $37 \%$ of firms having obtained a loan. Quantitatively, high performing firms, exporters, medium and large firms increase the probability of credit access. Findings indicate that having access to credit and long loan duration increase firm performance, while increase in the annual interest rate reduces firm productivity.

By way of policy implications, the governments in the EAC should put in place policies that are aimed at creating a stable and conducive microeconomic environment that can enhance the performance of firms and by extension increase their participation in the credit market. Governments in the region should tackle those business constraints rated as very severe by manufacturing firms; electricity outages, access to finance, high and volatile tax rates, corruption, and macroeconomic instability. Additionally, governments' policy in the region should make credit access easier by lowering the annual interest rates and also negotiating for a longer pay back period for individuals in the business sector to ensure maximum benefit from the loan. Easing loan accessibility to manufacturing firms will also present a great opportunity of increasing capital intensity given that East African countries are at an extreme disadvantage of producing capital goods and also that own savings may be inadequate to purchase machinery, equipment, plants, and land. Additionally, governments should ease the process and preconditions of business registration so that firms can easily move from sole proprietorship to partnership and eventually to privately held limited companies.

\section{References}

Aghion, P., Fally, T., \& Scarpetta, S. (2007). Credit constraints as a barrier to the entry and post-entry growth of firms. Economic Policy, 22, 731-779. http://dx.doi.org/10.1111/j.1468-0327.2007.00190.x

Angelini, P., \& Generale, A. (2008). On the evolution of firm size distributions. American Economic Review, 98(1), 426-38. http://dx.doi.org/10.1257/aer.98.1.426

Ayyagari, M., Beck, T., \& Demirgüç-Kunt, A. (2007). Small and medium enterprises across the globe: A new database. Small Business Economics, 29(4), 415-434. http://dx.doi.org/10.1007/s11187-006-9002-5

Banerjee, A. V., \& Duflo, E. (2004). Do firms want to borrow more? Testing credit constraints using a directed lending program. CEPR Discussion Paper 4681.

Beck, T. (2007). Financing constraints of SMEs in developing countries: Evidence, Determinants and Solutions, Mimeo.

Beck, T., Demirgüç, K. A., \& Levine, R. (2005). SMEs, growth, and poverty: Cross-country evidence. Journal of Economic Growth, 10, 197-227. http://dx.doi.org/10.1007/s10887-005-3533-5

Becker, B., \& Greenberg, D. (2005). Financial development and international trade, mimeo. University of Illinois at Urbana-Champaign.

Bigsten, A., Isaksson, A., Soderbom, M., Collier, P., Zeufack, A., Dercon, S., Fafchamps, M., Gunning, J. W., Teal, F., Gauthier, B., Oduro, A,. Oostendorp, R., \& Patillo, C. (2000). Rates of return on physical and human capital in Africa's manufacturing sector. Economic Development and Cultural Change.

Binks, M., \& Ennew, C. (1996). Growing firms and the credit constraint. Small Business Economics, 8(1), 17-25. http://dx.doi.org/10.1007/BF00391972

Cabral, M. B., \& Mata, J. (2003). On the evolution of the firm size distribution: Facts and theory. American Economic Review, 93(4), 1075-1090. http://dx.doi.org/10.1257/000282803769206205

Canepa, A., \& Stoneman, P. (2008). Financial constraints to innovation in the UK: Evidence from CIS2 and CIS3. Oxford Economic Papers, 60(4), 711-730. http://dx.doi.org/10.1093/oep/gpm044

Carpenter, R. E., \& Peterson, B. C. (2002). Is the growth of small firms constrained by internal finance? The 
Review of Economics and Statistics, 84(2), 298-309.

Chaffai, M., Landivar, D., \& Plane, P. (2011). Financial constraints and productivity under unobserved heterogeneity of the technology: An application to the Moroccan garment sector using latent class stochastic frontier models. CERDI Working Paper.

Cruickshank, D. (2000). Competition in U.K. Banking: A report to the chancellor of the exchequer. The Stationary Office: London.

Demirguc, K. A., \& Maksimovic, V. (1998). Law, finance and firm growth. Journal of Finance, 53, 2107-2137. http://dx.doi.org/10.1111/0022-1082.00084

Evans, D., \& Jovanovic, B. (1989). An estimated models of entrepreneural choice under liquidityt constraints. Journal of Political Economy, 97(4), 808-827. http://dx.doi.org/10.1086/261629

Fan, J., Titman, S., \& Twite, G. (2006). An international comparison of capital structure and debt maturity. HKUST Working Paper.

Guiso, L., Sapienza, P., \& Zingales, L. (2004). Does local financial development matter? Quarterly Journal of Economics, 119(3), 929-69. http://dx.doi.org/10.1162/0033553041502162

Hamilton, B. H. (2000). Does entrepreneurship pay? An empirical analysis of the returns to self-employment. Journal of Political Economy, 108(3), 604-631. http://dx.doi.org/10.1086/262131

Hart, O., \& Moore, J. (1994). A theory of debt based on the inalienability of human capital. Quarterly Journal of Economics, 109, 841-79. http://dx.doi.org/10.2307/2118350

Hottenrott, H., \& Peters, B. (2011). Innovative capability and financing constraints for innovation more money, more innovation? ZEW Discussion Papers 09-081, Center for European Economic Research.

Hyytinen, A., \& Toivanen, O. (2005). Do financial constraints hold back innovation and growth? Evidence on the role of public policy. Research Policy, 34(9), 1385-1403.

Jovanovic, B. (1982). Selection and the Evolution of Industry. Econometrica, 50, 649-670. http://dx.doi.org/10.2307/1912606

Kumar, A., \& Francisco, M. (2005). Enterprise size, financing patterns, and credit constraints in Brazil: Analysis of data from the investment climate assessment survey. Washington, DC: World Bank. http://dx.doi.org/10.1596/0-8213-6129-5

Kuntchev, V., Ramalho, R., Rodriguez-Meza, J., \& Yang, J. S. (2012). What have we learned from the enterprsie surveys regarding access to finance by SMEs?

Laeven, L. (2003). Does financial liberalisation reduce financing constraints? Financial Management, 32, 5-34. http://dx.doi.org/10.2307/3666202

Mata, J., \& Portugal, P. (2002). The survival of new domestic and foreign-owned firms. Strategic Management Journal, 23, 323-343. http://dx.doi.org/10.1002/smj.217

Mata, J., Portugal, P., \& Guimaraes, P. (1995). The survival of new plants: Start up conditions and post entry evolution. International Journal of Industrial Organization, 13, 459-481. http://dx.doi.org/10.1016/0167-7187(95)00500-5

Monge-Naranjo, A., \& Hall, L. (2002). Access to credit and the effect of credit constraints on Costa Rican manufacturing firms. Inter American Development Bank, Research Network Working Paper \#R-471. Retrieved from http://www.idb.int/

Ogujiuba, K. K., Ohuche, F. K., \& Adenuga, A. O. (2004). Credit availability to small and medium scale enterprises in Nigeria: Importance of new capital base for banks-Background and Issues. Working paper.

Ojah, K., Gwatidzo, T., \& Kaniki, S. (2010). Legal environment, finance channels and investment: The east $\begin{array}{lllll}\text { african } & \text { Sxample. Journal of Development }\end{array}$ http://dx.doi.org/10.1080/00220380903012722

Oliveira, B., \& Fortunato, A. (2006). Firm growth and liquidity constraints: A dynamic analysis. Small Business Economics, 27, 139-156. http://dx.doi.org/10.1007/s11187-006-0006-y

Pakes, A., \& Ericson, R. (1987). Empirical implications of alternative models of firm dynamics. SSRI Working Paper, University of Wisconsin, Madison

Rajan, G. R., \& Zingales, L. (1998). Financial dependence and growth. American Economic Review, 88, 559- 
586.

Titman, S., Fan, J., \& Twitie, G. (2003). An international comparison of cpital strcture and debt maturity choices. Social Schem Research Network Working Paper.

Tucker, J., \& Lean, J. (2003). Small firm finance and public policy. Journal of Small Business and Enterprise Development, 10(1), 50-61. http://dx.doi.org/10.1108/14626000310461367

Uganda Bureau of Statistics. (2006). Statistical Abstract, Uganda Bureau of Statistics. Kampala.

Ughetto, E. (2008). The financing of innovative activities by banking institutions: Policy issues and regulatory options. In B. Laperche \& D. Uzunidis (Eds.), Powerful finance and innovation trends in a high-risk economy. Palgrave Macmillan.

Winker, P. (1999). Causes and effects of financing constraints at the firm level. Small Business Economics, 12, 169-81. http://dx.doi.org/10.1023/A:1008035826914

World Bank. (2006). World bank investment climate survey, 2007. The World Bank, Washington, DC. Retrieved from: http://www.enterprisesurveys.org/rawdata.aspx

\section{Notes}

Note 1. The World Bank enterprise survey (2006) is based on the same sampling frame and collects data on the same features of firm entreperises.

Note 2. Firms with limited stock find it difficult to provide adequate collateral assets.

\section{Copyrights}

Copyright for this article is retained by the author(s), with first publication rights granted to the journal.

This is an open-access article distributed under the terms and conditions of the Creative Commons Attribution license (http://creativecommons.org/licenses/by/3.0/). 